\title{
OPTIMIZATION OF BOX TYPE GIRDER WITH AND WITHOUT INDUSTRIAL CONSTRAINTS
}

\author{
MUHAMMAD ABID ${ }^{1 *}$, SHAHBaZ MaHMOOD KHAN ${ }^{2}$, \\ AND HAFIZ ABDUL WAJID ${ }^{3,4}$ \\ ${ }^{1}$ Interdisciplinary Research Center, COMSATS Institute of information Technology, \\ Wah Cantt, Pakistan. \\ ${ }^{2}$ Faculty of Mechanical Engineering, GIK Institute of Engineering Sciences and \\ Technology, Topi, KPK, Pakistan. \\ ${ }^{3}$ Department of Mathematics, COMSATS Institute of information Technology, \\ Lahore, Pakistan. \\ ${ }^{4}$ Department of Electrical Engineering, Islamic University Medina, \\ Kingdom of Saudi Arabia. \\ *Corresponding author:drabid@ciitwah.edu.pk \\ (Received: $26^{\text {th }}$ May 2017; Accepted: $30^{\text {th }}$ Dec 2017; Published on-line: $1^{\text {st }}$ June 2018)
}

https://doi.org/10.31436/iiumej.v19i1.769

\begin{abstract}
In this paper three dimensional nonlinear finite element analysis is performed for the optimization of an overhead crane box girder for capacity (50 120ton) and span $(10 \sim 32 \mathrm{~m})$ for safe bending stress and deflection with minimum mass and volume. A customized optimization code is developed using interpolative relations and correction factors to achieve optimized results with and without considering industrial constraints. A cutting and welding plan is developed to provide a standard operating procedure for the manufacturing of the box girder. Bill of materials, box girder design dimensions, and cutting and welding lengths are recorded with considerable time saving.
\end{abstract}

ABSTRAK: Kertas ini mengkaji tentang analisis tidak linear tiga dimensi unsur terhingga bagi mengoptimumkan kotak kren galang atas kepala bagi kapasiti (50 120 tan) dan pada kadar $(10 \sim 32 \mathrm{~m})$ bagi takat lentur selamat dan pesongan dengan jisim minimum dan isipadu. Kod optimum penyesuaian telah direka mengguna pakai kaitan interpolatif dan faktor-faktor pembetulan bagi mencapai keputusan yang optimum, dengan dan tanpa mengambil kira kekangan industri. Pelan pemotongan dan kimpalan telah dicipta bagi menyediakan prosedur operasi biasa bagi pembuatan kotak galang. Rang undang-undang bahan, dimensi reka bentuk kotak galang, pemotongan dan panjang kimpalan telah direkodkan dengan penjimatan masa yang besar.

KEYWORDS: box girder; optimization; industrial; bill of materials; cutting; welding; finite element analysis; industrial constraints

\section{INTRODUCTION}

Overhead cranes are machines that are used to handle and transfer heavy loads from one place to another in shipping, automotive, logistics, and construction industries [1-2]. The use of cranes enhances efficiency, reliability, and productivity of processes by reducing the human effort and time for handling and moving heavy objects [3-4]. The cranes are regarded as critical material handling devices [5-15]. Therefore, crane safety during operation is immensely important. ASME - ANSI [16]; ISO [17]; CMAA [18]; DINTaschenbuch [19]; F.E.M. rules [20]; British standards [21]; and Polish standards [22] are 
organized to standardize and regulate the manufacturing and safe operation of these cranes. Greiner's Crane Handbook [23] provides important information regarding crane design, manufacturing, and operation. Otani et al. [24] described the vertical seismic response of a 150 -ton box girder crane of $35 \mathrm{~m}$ and concluded that a linear analysis was sufficient to find the reaction forces on the wheels even when the leap phenomenon had occurred in the overhead crane. Alkin et al. [25] used shell and solid elements for the optimization of 32ton and $13 \mathrm{~m}$ span crane. Farkas [26] studied the economy of the crane as a function of yield strength of the material used for the crane construction. Niezgodzinski and Kubiak [27] used experimental, analytical and numerical methods to study the effect of a local stability problem in box girder cranes and concluded that the addition of strips stiffens the web and reduces the chance of buckling. Zuberi et al. [1] used non-linear Generalized Reduced Gradient optimization code for the optimization of overhead crane box girders using available standards by CMAA and Greiner's Crane Handbook. Case studies were performed using 10-50 ton capacity and $22 \mathrm{~m}, 25.5 \mathrm{~m}, 27.5 \mathrm{~m}$, and $30 \mathrm{~m}$ span cranes. The diaphragm spacing and proper thickness was concluded vital for mass minimization. Imrak et al. [28] studied the linear and non-linear finite element behavior of a portal crane of $200 \times 2$ ton capacity and $100 \mathrm{~m}$ span. Beam and shell elements were used during the modeling of the crane. Blum and Chodorowska [29] investigated the pre-stressing phenomenon in plate welded girders, mostly of the fillet welds. They concluded that the pre-stressed model is significantly stable and stiffened as compared to the non-pre-stressed model. Abid et al. [30] optimized box girders of 150 ton and $32 \mathrm{~m}$ span to control buckling with proper quantity and positions of stiffeners. Pinca et al. [31,32] performed finite element analysis using shell elements for box girders and achieved a $21 \%$ theoretical mass reduction. Gerdemeli et al. $[33,34]$ performed finite element analysis using ANSYS and ABACUS software for gantry cranes and concluded that simulation helps in the optimization of structures, increased reliability, durability, reduced cost, and manufacturing duration. Gašić et al. [35] performed a dynamic analysis of cranes. Zhang et al [36] presented finite element analysis of box girder beams for transport bridges. Bećirović et al. [37] analyzed box girders of a 7 ton and $20 \mathrm{~m}$ span crane for cross-section optimization by changing its height-to-width ratio and the thicknesses of the plates and concluded a 38\% mass reduction. Gąska and Pypno [38] studied static and dynamic stability of 20 ton cranes of various spans according to Polish and English standards. Lerga [2] proposed a design modification in existing designs of box girders of overhead cranes and concluded a 5.5\% mass reduction. Djelosevic et al. [39] studied the local stress parameters of box and trapezoidal girders and concluded that trapezoidal sections have lower localized stress influence as compared to the straight sections. Capacity and span-wise optimization were performed by Abid et al. [40, 41] and relations and optimization factors were developed for a capacity range of 50 120 ton and a span range of $10 \mathrm{~m} \sim 32 \mathrm{~m}$. Chauhan and Bhatt [42] performed finite element analysis using three different steels (EN-22, Steel-20 and Forged steel) for the hook for a 10 ton and $22 \mathrm{~m}$ span crane girder to study possible increase in its durability and minimum stresses were recorded for EN-22. Suratkar and Shukla [43] performed finite element simulation of a 10 ton and $12 \mathrm{~m}$ span crane box girder using a five-point load model i.e. four points for the divided load and one point for the displaced centered load for the payload. It was concluded that the stresses produced were much less than the allowable stress values, thus proposed the optimization of the analyzed model. Rabey [44] using a ST-3-PS steel girder, performed an analysis with 1, 8, and 16 ton payloads and studied the behavior of the girder under collision. He proposed to implement standardized dynamic parameters for the collisions of bridge cranes and end stops. Haniszewski [45] performed dynamic modeling of an overhead travelling crane and interaction of the dynamic geometric model with the finite element mode. An intricate geometric model was generated for a 5 ton and $20 \mathrm{~m}$ span crane for both 
static and Lanczos modal analysis. The static analysis was carried out for self-weight and applied load cases for loaded and unloaded cases. The loaded case was concluded critical under both the static and dynamic loading conditions.

Most of the available works have considered a single capacity or single span for optimization and take almost no consideration for industrial or manufacturing strategies. This paper discusses the results of automated optimization code developed using ANSYS Parametric Design Language (APDL) and implemented for design optimization using developed correction factors without considering the industrial constraints. The box girder without industrial constraints (WOIC) is the one in which design variables such as $H_{M A X}$ maximum height of the girder, RD - web plate thickness factor, and PT- flange plate thickness factors are modified independently as mentioned by Abid et al. [40, 41]. Later, using an automated optimization routine considering industrial constraints, optimized cutting lengths, welding lengths, edge preparation lengths, and manufacturing strategy is developed for reduced waste, mass, and efforts, after which the results are recorded. The box girder with industrial constraints (WIC) is one in which $\mathrm{H}_{\mathrm{MAX}}$ is constrained equal to the sizes available in the market. The width of the top plate is also constrained to one-third of $H_{M A X}$. Two approaches for box girders with industrial constraints have been considered: (1) keeping all thicknesses the same i.e. $T_{S P}$ (thickness of side plate) $=T_{T P}$ (thickness of top plate) $=T_{B P}$ (thickness of bottom plate); (2) keeping web and flange thickness different.

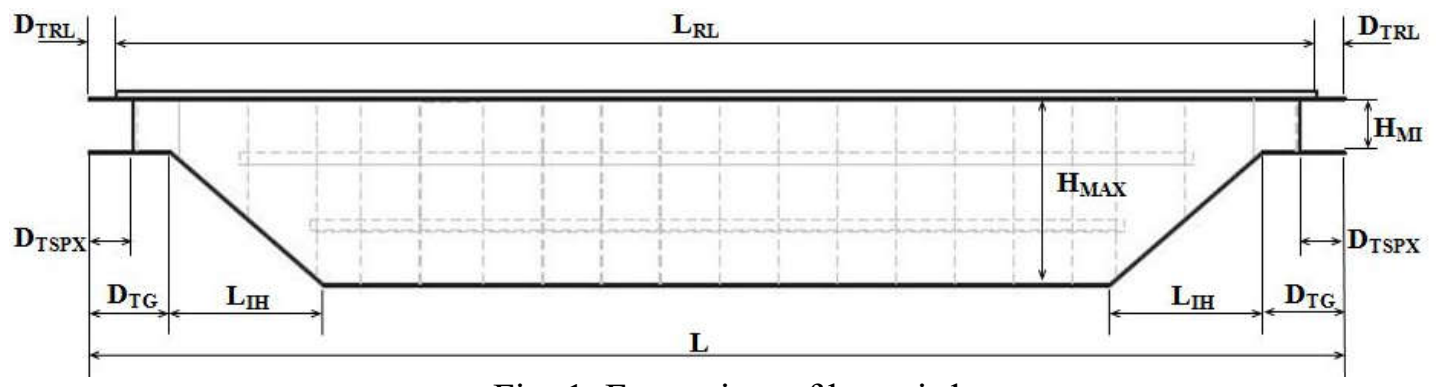

Fig. 1: Front view of box girder .

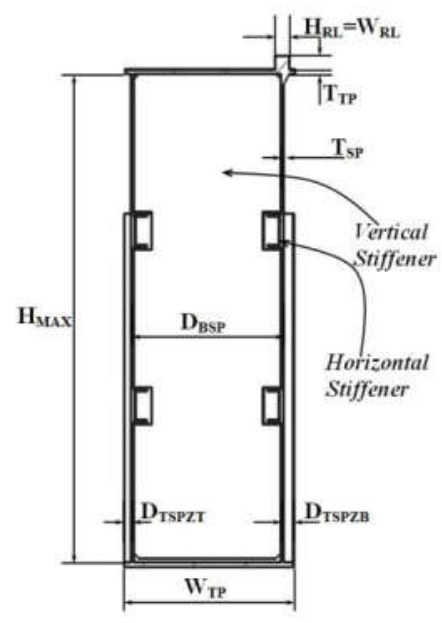

(a)

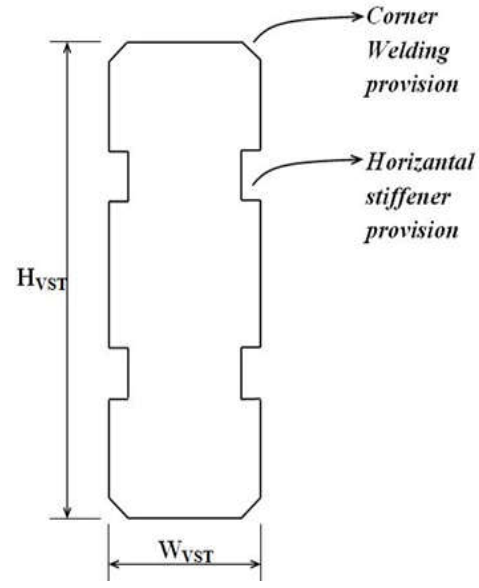

(b)

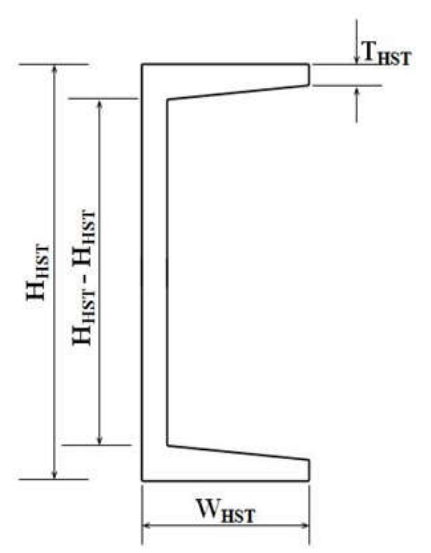

(c)

Fig. 2: Section view of box girder, (b) vertical stiffener, (c) horizontal stiffener 

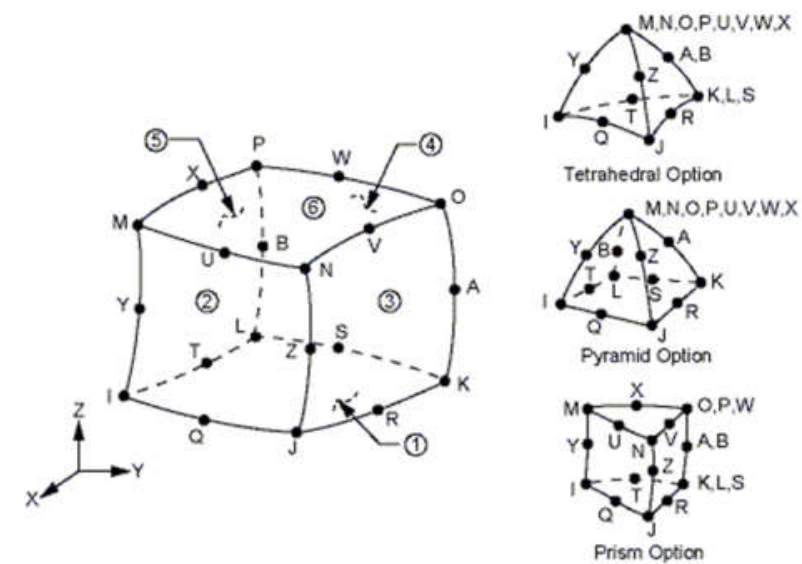

Fig. 3: Solid 186 element in ANSYS [47].

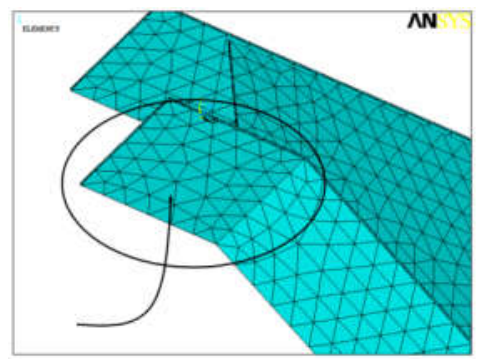

(a)

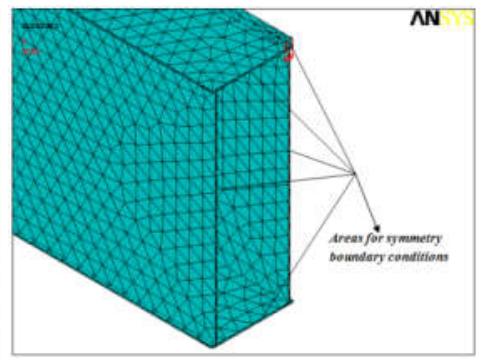

(b)

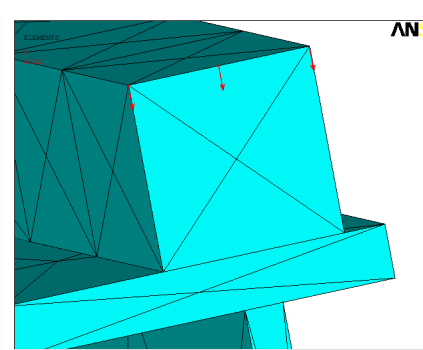

(c)

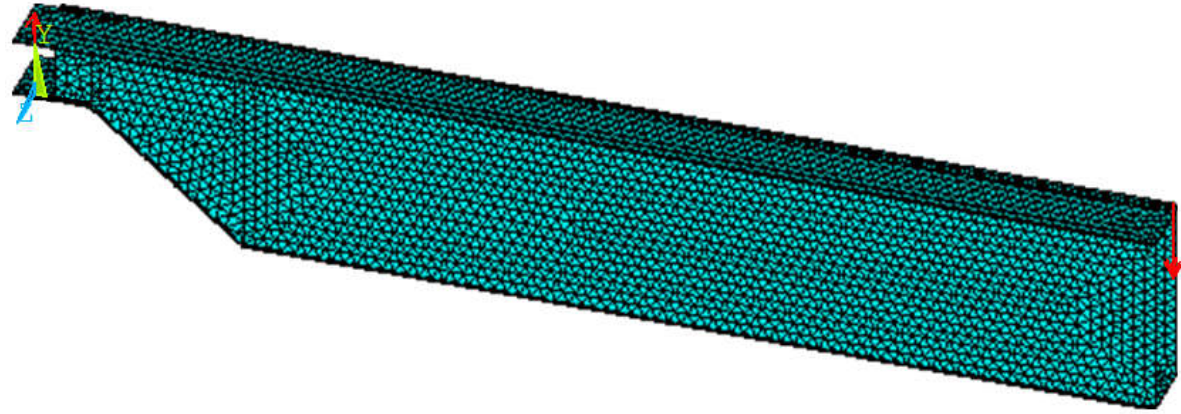

(d)

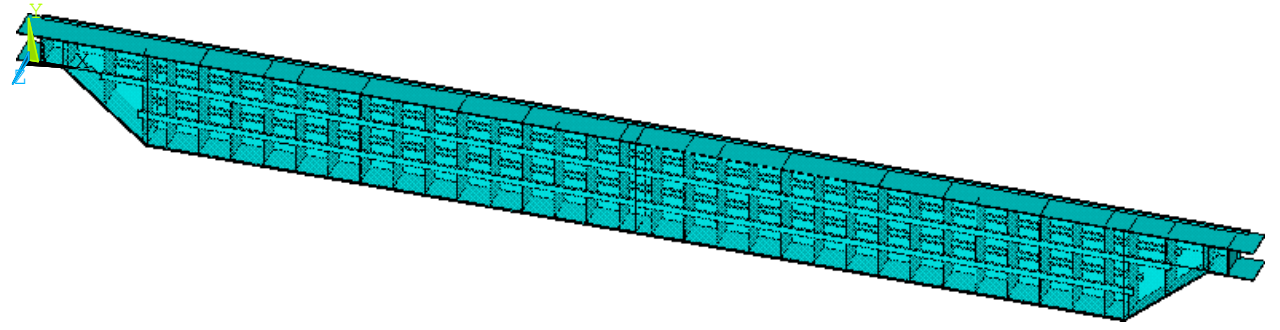

(e)

Fig. 4a-e: Applied boundary conditions; (d) meshed model, (e) cut view of full geometry modeled with horizontal and vertical stiffeners.

For the optimization of box girders of a capacity range of 50 120 ton and for a span of $10 \sim 32 \mathrm{~m}$, a detailed 3D nonlinear finite element analysis is performed. Initially, a 120 ton girder is optimized as the reference girder first by adding horizontal and vertical stiffeners to control torsion, buckling, and deflection within allowable limits [46]. Later, this 
reference optimization is used for capacity-wise [40], span-wise [41] and combined optimizations in the present study.

\section{BOX GIRDER MODELING; MESHING, BOUNDARY CONDITIONS AND MATERIAL SELECTION}

Figure 1 shows the front view of a box girder with general parameters; Figure 2a-c shows the sectioned view of the box girder, and vertical and horizontal stiffeners, respectively; Figure 4a-c show applied boundary conditions (constraints, loading and reflective symmetry). Figure 4d shows meshing of the half box girder model using Solid186 elements; Figure 4e shows a section view of the full geometry modeled with horizontal and vertical stiffeners. Most of the researchers used shell elements dealing with finite element analysis of box girders [1, 27 45]. Researchers have selected shell elements owing to fact that the box girder cranes are classified as thin walled structures [45]. The geometries they use is therefore simplified, neglecting features like rails and horizontal sections. Use of solid elements is also found in the literature [3, 25, 30, 43], as these can be used for both thick and thin sections. Due to the use of solid elements, only a single element type is required, therefore avoiding interfacing of element types. Also, because the present study uses batch mode (by using APDL code), better control during parametric modeling is incurred. In the present study, Solid186 (20 noded) element is used for discretization of the geometric model (Fig. 3 and meshed model in Fig. 4(d)). A half model was created due to the symmetry of the geometry. For meshing, the element edge length at this stage was set to $180 \mathrm{~mm}$ and at a later stage, during optimization, the edge length was selected by performing element sensitivity analysis to reduce error. Because the optimization includes various sizes, the element edge length and the number of elements changes. For all optimized sizes, the element edge length was between $50-150 \mathrm{~mm}$. A sample mesh sensitivity study is presented by authors in previous work [41]. ANSYS software [47] was used for finite element analysis. An ANSYS Parametric Design Language (APDL) code was developed that was utilized to run the simulations in batch mode. The code, when entered in ANSYS, asks for two entities i.e. span and capacity. Only these two inputs and the interpolative relations and correction factors determined in the present work are utilized to present the optimized parameters of the required size and capacity crane.

The boundary conditions are as follows:

(1) A single line load on the halfway of a rail equally divided on three nodes thus reducing stress singularity;

(2) A loading impact factor of 1.25 is selected i.e. a 120 ton crane has a load of $120 *$ $1.25=150$ ton and additionally its own weight.

(3) A zero degree-of-freedom boundary condition is applied for all nodes on the support area (this is a purposely selected conservative approach);

(4) Symmetry condition at half length of girder;

(5) Gravitational acceleration to include the effects of self-weight are applied.

Structural materials for the construction of overhead crane girders i.e. RST-37-2 [25,30], St-42 [33], St-52-3 [34], structural steel [2], IS: 2062, E 250B [42], structural steel S235 [45], and others are used. The most commonly available structural steel according to ASTM standard is A36 / A36M [46] and is an equivalent alternative of RST-37-2 according to DIN standard 17100. Material A36 having elastic modulus $=200 \mathrm{GPa}$, yield strength $=$ $250 \mathrm{GPa}$, ultimate tensile strength $=400 \sim 550 \mathrm{GPa}$, allowable stress $=160 \mathrm{MPa}$ and density $=7.86 \times 10^{-6} \mathrm{~kg} / \mathrm{mm}^{3}$ is used for analysis in this study. Although allowable deflection is a matter of professional judgment, the values of deflection must be between L/360 - L/180 to 
avoid visible sagging [50]. A box girder without proper stiffening will show lateral buckling (Fig. 5). Reference [30] utilized optimized positions and number of vertical and horizontal stiffening elements to reduce the deflection in the lateral direction, hence to avoid lateral buckling. The present study utilizes this approach to control lateral buckling.

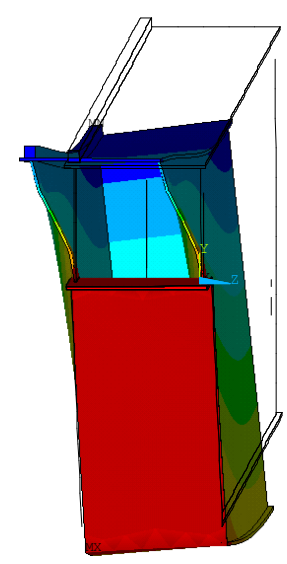

(a)

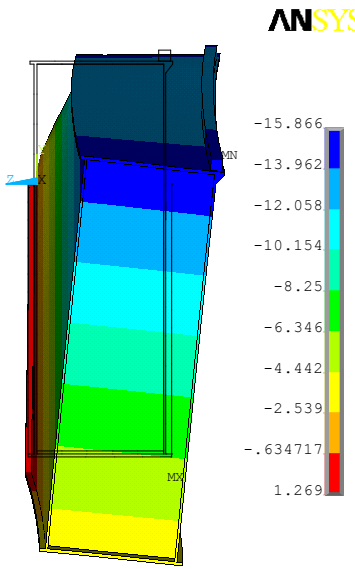

(b)

Fig. 0: lateral bucking (UZ Plot in $\mathrm{mm}$ ) at (a) Support; (b) Center.

\section{OPTIMIZATION METHODOLOGY WITHOUT CONSIDERATION OF INDUSTRIAL CONSTRAINTS}

Capacity-wise optimization optimizes box girders of different capacities of the same span and thus has capacity as the only input and is presented in [40]. Span-wise optimization optimizes box girders of different spans and same capacity, thus has span as the only input and is presented in [41]. These studies use first order optimization using the ANSYS design optimization module with the overall mass and volume of the box girder as the objective parameter. The maximum number of iterations was set to 50. The maximum height $\left(H_{M A X}\right)$ and web and flange thicknesses were design variables. Other size parameters are related to these design variables. The maximum normal stress and normal deflections were the state variables. For capacity-wise optimization, this is repeated for $32 \mathrm{~m}$ box girders and different capacities between 50-120 tons. Likewise, during span-wise optimization, design optimization is carried out with 100 ton girders with span between 10-32 m. The results of each are generalized in the form of interpolative relations. Although, the authors first optimized capacity-wise and then span-wise, the reverse approach is considered equally valid. The capacity-wise and span-wise optimization methodologies are presented in Fig. 6a and $6 \mathrm{~b}$, respectively. The interpolative relations developed during the capacity-wise and span-wise optimization are presented in relations (1 3) and (4 6), respectively. Relations $(1 \sim 3)$ are only valid for $32 \mathrm{~m}$ box girders of capacity range of $50 \sim 120$ ton and relations (4 6) are only valid for 100 ton box girders of span range of $10 \sim 32 \mathrm{~m}$.

$$
\begin{aligned}
& \left(H_{M A X}\right)_{C}=\left(H_{M A X}\right)_{R^{-}}\left\{\left[\left(H_{M A X}\right)_{R} \times(R C-C C) / 400\right]+H C F \times(R C-C C)\right\} \\
& (R D)_{C}=(R D)_{R^{-}}[(R C-C C) / 400]
\end{aligned}
$$


$(P T)_{C}=(P T)_{R^{-}}[(R C-C C) / 200]$
$\left(H_{M A X}\right)_{C}=\left\{\left(H_{M A X}\right)_{R}-\left\{0.11 \times\left[(H L)_{R^{-}}\right.\right.\right.$
$\left.\left.\left.(H L)_{C}\right]\right\}\right\}+75$
$(R D)_{C}=\left\{(R D)_{R^{-}}+\left\{0.0000365 \times\left[(H L)_{R^{-}}(H L)_{C}\right]\right\}\right\}-0.05$
$(P T)_{C}=\left\{(P T)_{R^{-}}\left\{0.00009375 \times\left[(H L)_{R^{-}}\right.\right.\right.$
$\left.\left.\left.(H L)_{C}\right]\right\}\right\}-0.002$

Where, $R C$ is the capacity of the reference girder; $C C$ is the capacity of the current girder; $H C F$ is the height correction factor; $(H L)_{R}$ and $(H L)_{C}$ are half of the span length of reference and current girder respectively; and $R D$ and $P T$ are reduction factors.

In order to develop relations for any given span and capacity, a generalized (APDL) code is developed based on the factors and relations developed during the span-wise and capacity-wise optimization routines and a generalized optimized code for combined capacity and span is developed and tested, with its results discussed in detail.

The following relations are introduced for more useful dependencies:

$$
\begin{aligned}
& H_{M A X}=f\left(H_{M A X l}, H L\right) \\
& R F=f(R F 1, H L) \\
& P T=f(P T 1, H L)
\end{aligned}
$$

Where, $H_{M A X 1}, R F 1$ and $P T 1$ are the maximum height, web thickness, and flange thickness optimization factors calculated during the capacity-wise optimization and $H_{M A X}, R F$ and $P T$ are the height and thickness factors calculated during span-wise relations. The aim is to define dependencies in such a way that the span-wise optimization relations are in terms of capacity-wise relations. Thus, the optimization factors calculated in the capacity-wise calculations become inputs for the relations developed in the span-wise calculations. There are some correction or combination factors used to make these relations compatible with each other. Finally, the capacity-wise relations act as the capacity control block and correction factors form correction block and finally the span-wise relations control the span related issues.

$$
\begin{aligned}
& \left(H_{M A X}\right)_{1}=2600-((2600 \times 0.0025 \times(120-C C))+(120-C C)) \\
& (R F)_{1}=0.727-(0.0025 \times(120-C C)) \\
& (P T)_{1}=1.85-(0.005 \times(120-C C))
\end{aligned}
$$

The span control block consists of the following modified span-wise interpolative relations:

$$
\begin{aligned}
& \left(H_{M A X}\right)=\left(\left(H_{M A X}\right)_{1}-(C M F \times(16000-H L))\right)+S P C \\
& \left.(R F)=(R F)_{1}+(0.0000365 \times(16000-H L))\right)-R D C \\
& \left.(P T)=(P T)_{1}-(0.00009375 \times(16000-H L))\right)-P R C
\end{aligned}
$$




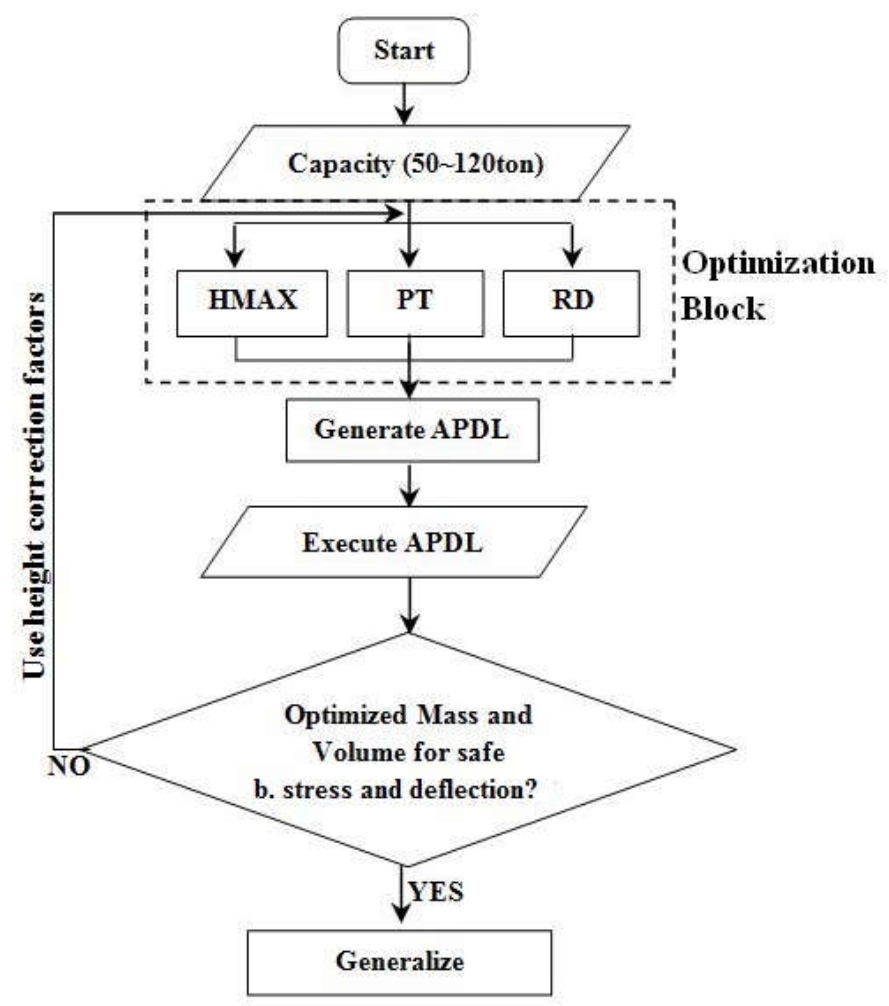

(a)

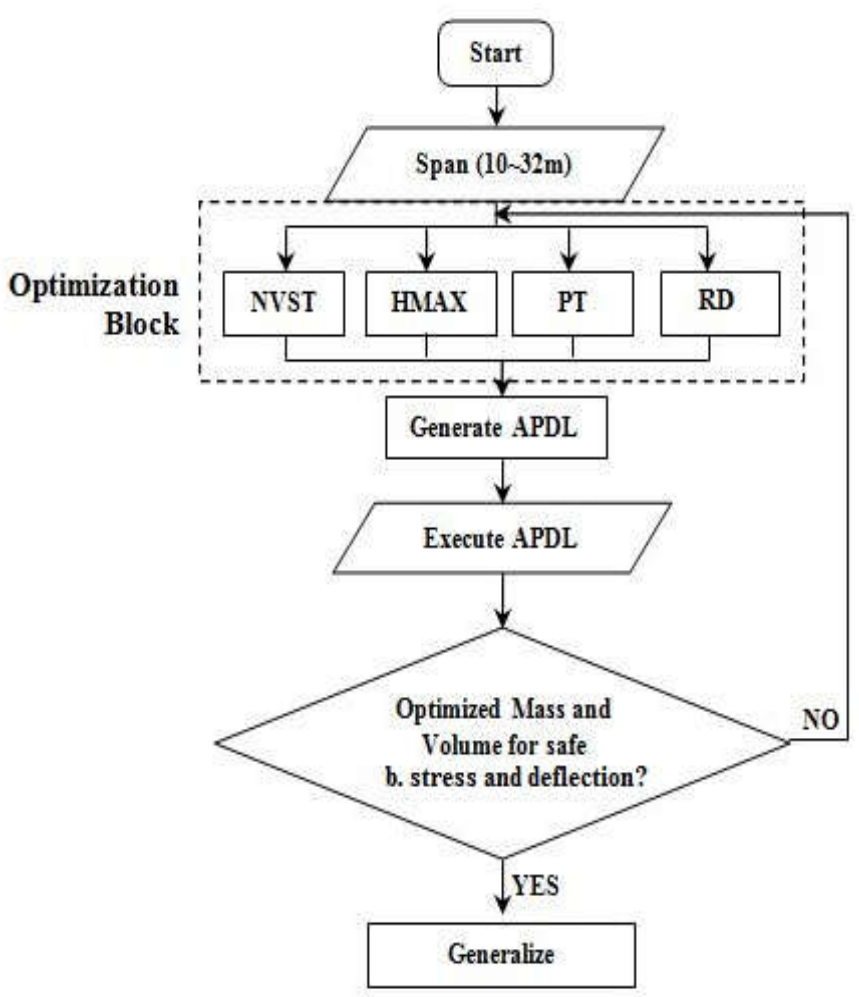

(b)

Fig. 6: (a) Capacity wise optimization (b) Span wise optimization. 
The capacity control block consists of the following modified capacity-wise interpolative relations:

Where $S P C$ is the maximum span control factor with a value of -125 and is only used for 32 $\mathrm{m}$ span box girders for any capacity; $C M F$ is the height compensation factor for all spans; $R D C$ is the side plate control factor that works for all spans in the range; $P R C$ is the top and bottom plate control factor; $C C$ is the capacity of the giver sized girder; and $H L$ is the half of the span.

The general methodology for combined optimization is given in Fig. 7. As a case study, correction factors for 50 120 ton capacity and different spans are summarized in Table 1 .

Table 1: Correction factors for capacity 50 120 ton for different span ranges

\begin{tabular}{cccccc}
\hline Capacity (ton) & \multicolumn{2}{c}{ Span (m) } & \multicolumn{3}{c}{ Correction Factors } \\
\hline \multirow{3}{*}{$50 \sim 60$} & from & to & CMF & RDC & PRC \\
& 30 & 32 & 0.180 & 0.050 & 0.002 \\
& 24 & 26 & 0.115 & 0.050 & 0.002 \\
\multirow{3}{*}{$60 \sim 80$} & 10 & 12 & 0.100 & 0.050 & 0.002 \\
& 30 & 32 & 0.175 & 0 & 0 \\
& 22 & 26 & 0.115 & 0 & 0 \\
$80 \sim 100$ & 10 & 16 & 0.097 & 0.050 & 0.002 \\
& 30 & 32 & 0.175 & 0 & 0 \\
& 24 & 28 & 0.115 & 0 & 0 \\
$100 \sim 120$ & 10 & 12 & 0.102 & 0.050 & 0.002 \\
& 30 & 32 & 0.175 & 0 & 0 \\
& 24 & 26 & 0.115 & 0 & 0 \\
& 10 & 12 & 0.114 & 0.100 & 0.002 \\
\hline
\end{tabular}

As a case study, calculations are presented below using combined optimization strategy for a sample girder of 75 ton capacity and $26 \mathrm{~m}$ span box girder.

\subsection{Capacity Control Block}

Using equations 10 through 12 ; the values of $H_{M A X},(R F)_{1}$ and $(P T)_{1}$ are calculated to be $2262.5 \mathrm{~mm}, 0.6145$, and 1.625 respectively.

\subsection{Correction Block}

The correction factors are used from Table 1 i.e. for 75 ton $\times 26 \mathrm{~m}, S P C=0$ (as the span is not equal to $32 \mathrm{~m}), C M F=0.143, R D C=0$, and $P R C=0$.

\subsection{Span Control Block}

From relations 13 through 15; as the span is $26 \mathrm{~m}, H L$ (half-length in $\mathrm{mm}$ ) $=26 / 2 * 1000$ $=13000 \mathrm{~mm}, H_{M A X}, R F$, and $P T$ are calculated as $1833.5 \mathrm{~mm}, 0.724$, and 1.34375, respectively. Therefore, the optimized 75 ton $\times 26 \mathrm{~m}$ girder will have the $H_{M A X}=1833.5$ $\mathrm{mm}, R D=0.724, P T=1.34375$. However, thickness of side and top plates can be calculated using equations 16 and 17 respectively,

$$
T_{S P}=16 \times R F
$$


So, $\quad T_{S P}=16 \times 0.724=11.584 \mathrm{~mm}$

and, $\quad T_{T P}=T_{S P} \times P T$

$T_{T P}=11.584 \times 1.34375=15.566 \mathrm{~mm}$

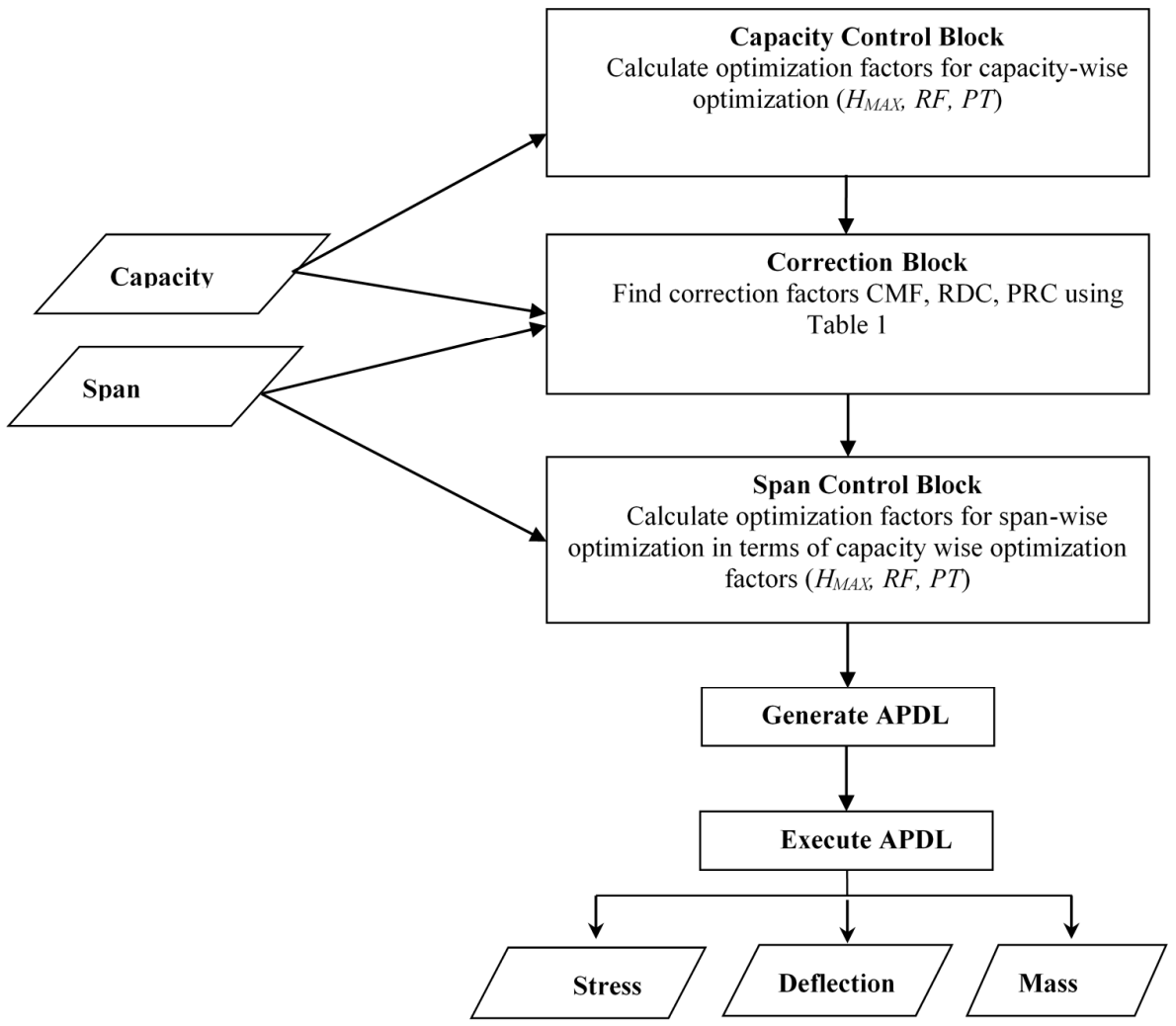

Fig. 7: Methodology for combined optimization.

Figure 8a presents a comparison of results of capacity-wise optimizations with $32 \mathrm{~m}$ span of girders with the results of the combined optimization methodology. Figure $8 \mathrm{~b}$ presents the comparison of span-wise optimization results of 100 ton girders with the combined optimization methodology. As case study, results of combined optimization methodology for 120 ton, 80 ton, and 50 ton capacity and 10, 20, 30, and $32 \mathrm{~m}$ span box girders are summarized in Table 2.

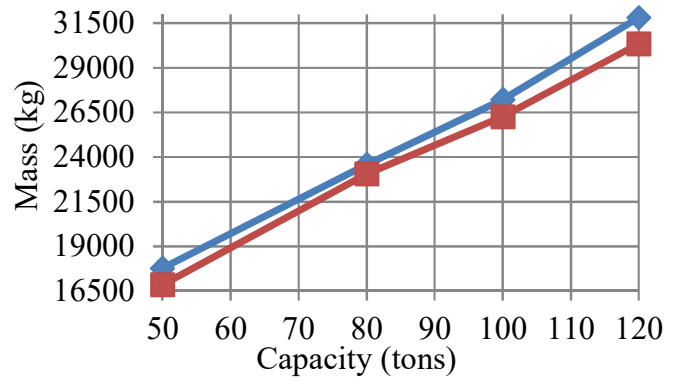

(a)

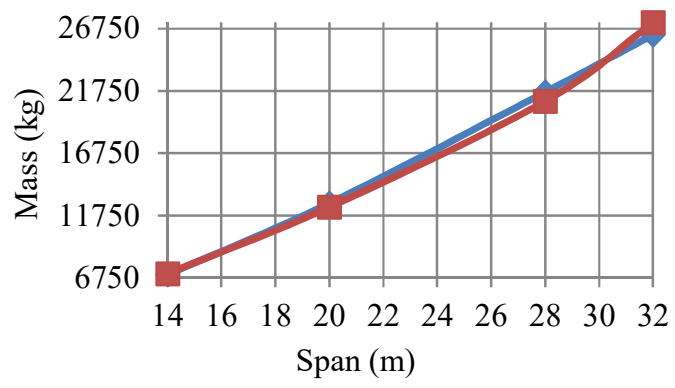

(b)

Fig. 8: (a) Comparison of capacity-wise and combined results of $32 \mathrm{~m}$ span box girders,

(b) Comparison of span-wise and combined results of 100 ton capacity box girders. 
Table 2: 50, 80, and 120 ton capacity girders after combined optimization

\begin{tabular}{cccccccccccc}
\hline $\begin{array}{c}\text { Capacity } \\
\text { Ton }\end{array}$ & $\begin{array}{c}\text { Span } \\
\mathbf{m}\end{array}$ & $\begin{array}{c}\mathbf{H}_{\mathbf{M A X}} \\
\mathbf{m m}\end{array}$ & $\begin{array}{c}\mathbf{T}_{\mathbf{S P}} \\
\mathbf{m m}\end{array}$ & $\begin{array}{c}\mathbf{T}_{\mathbf{T P}} \\
\mathbf{m m}\end{array}$ & $\begin{array}{c}\mathbf{W}_{\mathbf{T P}} \\
\mathbf{m m}\end{array}$ & $\begin{array}{c}\mathbf{H}_{\mathbf{R L}} \\
\mathbf{m m}\end{array}$ & $\begin{array}{c}\mathbf{T}_{\text {HS }} \\
\mathbf{m m}\end{array}$ & $\begin{array}{c}\text { MBS } \\
\mathbf{M P a}\end{array}$ & $\begin{array}{c}\text { USUM } \\
\mathbf{m m}\end{array}$ & $\begin{array}{c}\text { UZ } \\
\mathbf{m m}\end{array}$ & $\begin{array}{c}\text { MASS } \\
\mathbf{k g}\end{array}$ \\
\hline 120 & 32 & 2525 & 12 & 22 & 878 & 70 & 8 & 154.1 & 39.4 & 6.1 & 30330 \\
& 30 & 2400 & 13 & 22 & 834 & 66 & 7.5 & 156.4 & 35.1 & 5.3 & 27900 \\
& 20 & 1850 & 16 & 21 & 643 & 51 & 6 & 154.4 & 18.9 & 3.0 & 14604 \\
& 10 & 1313 & 17 & 14 & 457 & 36 & 3.5 & 154.8 & 6.5 & 1.6 & 3058 \\
80 & 32 & 2160 & 11 & 19 & 751 & 60 & 6.75 & 155.9 & 44.2 & 6.0 & 23050 \\
& 30 & 2125 & 11 & 18 & 739 & 59 & 6.75 & 154.4 & 39.0 & 5.5 & 20910 \\
& 20 & 1670 & 14 & 16 & 580 & 46 & 5.25 & 151.5 & 19.5 & 2.9 & 11150 \\
& 10 & 1178 & 16 & 10 & 410 & 33 & 3.75 & 150.2 & 6.4 & 1.4 & 3530 \\
50 & 32 & 1950 & 9 & 14 & 678 & 54 & 6 & 154.4 & 46.5 & 6.3 & 16848 \\
& 30 & 1895 & 9 & 13 & 659 & 53 & 6 & 156.5 & 42.3 & 5.8 & 15002 \\
& 20 & 1445 & 12 & 12 & 502 & 40 & 4.5 & 155.5 & 21.7 & 2.9 & 8020 \\
& 10 & 975 & 15 & 8 & 339 & 27 & 3 & 155.2 & 7.1 & 1.2 & 2640 \\
\hline
\end{tabular}

\section{OPTIMIZATION METHODOLOGY CONSIDERING INDUSTRIAL CONSTRAINTS}

The aim of the research is not only the optimization of the overhead crane box girders but also to optimize it in accordance with industrial constraints. The size of the plates for side, top, bottom, and vertical stiffeners; rail and horizontal stiffener sections calculated during the optimization were not realistic, being in fractions and mostly not corresponding to sizes available in the market. Therefore, in order to make the optimized design more practical: standard libraries for the standard sections i.e. standard plates, rails, and horizontal stiffeners [48] as available in the market are added. The optimized parameters are modified according to the standard size libraries. Finally, standard section libraries are added in the APDL code and optimized sections are achieved by selecting the closest available option for a given design variable that is used in the modeling and analysis instead of the ones calculated without considering industrial constraints.

Figure 9 compares the mass of 100 ton box girders before and after the addition of standard sizes. With the inclusion of standard sizes, the mass of the optimized box girders is increased and the maximum bending stresses are mostly found to have decreased due to the fact that a bigger or thicker section is always selected. Hence, the over-design caused is unavoidable as the selection of the small or thin sizes mostly tends to cause under-design. However, in order to control mass and waste of material during cutting, and to reduce manufacturing cost: cutting and welding plans, modification of height and width of the plates is introduced and are discussed in the following sections.

\subsection{Height Modification}

The design variables of the box girders optimized without industrial constraints are modified and re-optimized to design box girders with industrial constraints. The sizes of A36 structural steel plates, in terms of height and width, are according to State Steel USA's product catalogue [48], and are presented in Table 3. It is observed that the difference between the heights is $304 \mathrm{~mm}(1524-1219.2=304.8 \mathrm{~mm})$ except the last size. Therefore, if a constraint is added in such a way that the APDL code selects the closest, then the mass increases, which is not desired. Another methodology is to sustain the heights of the plates calculated during the WOIC optimization and cutting and welding the plates together. This 
causes an increase in the cost of manufacturing. This also causes an increase in deformations during welding, resulting in structural weakening. In order to overcome the above mentioned issues, the box girders are re-optimized for maximum height $\left(H_{M A X}\right)$ equal to the ones that are available in the market. The first four sizes $(1219.2 \mathrm{~mm}, 1524 \mathrm{~mm}, 1828.8 \mathrm{~mm}$ and $2133.6 \mathrm{~mm}$ ), as mentioned in the Table 3, were selected. As all parameters other than the height and thickness of plates depend upon the $\mathrm{H}_{\mathrm{MAX}}$ optimization factor, therefore, the only design variables left after having $H_{M A X}$, is the thickness of the side, top, and bottom plates. Thus, the optimization for height modification is done by changing the thicknesses of web and flange plates. The height of the plates is selected according to the $\mathrm{H}_{\mathrm{MAX}}$ calculated in the previous optimizations and is divided into ranges as mentioned in Table 4.

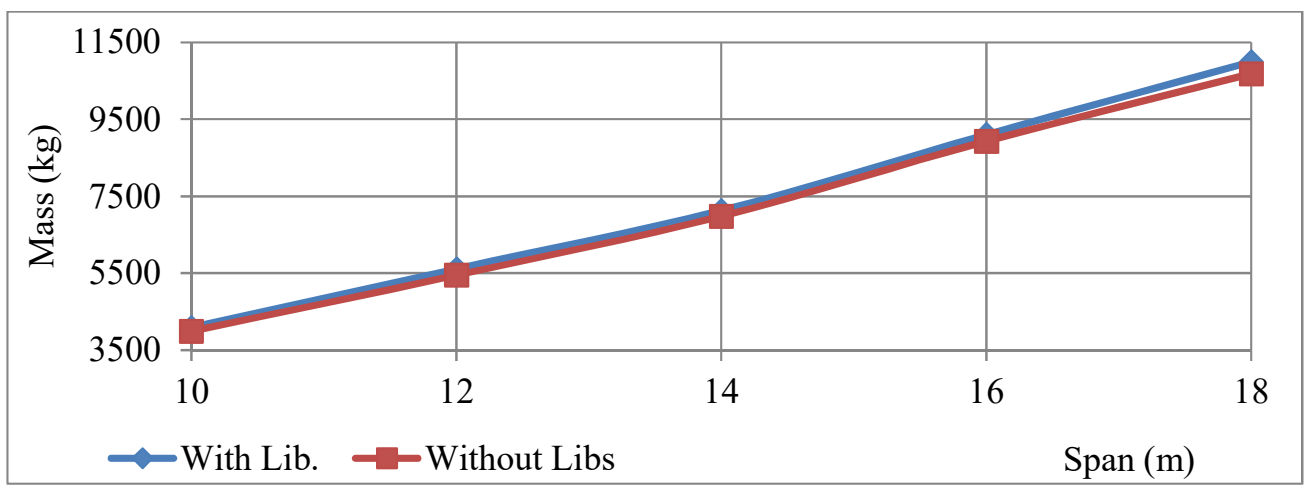

Fig. 9: Mass comparison of 100 ton girder with and without industrial constraints.

Two approaches were used during this optimization:-

- $\quad$ Keeping all thicknesses the same i.e. $\mathrm{T}_{\mathrm{SP}}=\mathrm{T}_{\mathrm{TP}}=\mathrm{T}_{\mathrm{BP}}$. (Approach 1).

- Keeping web thicknesses and flange thicknesses different from one another, but keeping the thickness of the top and bottom flange the same and left and right web plates the same. (Approach 2).

Table 3: Standard available heights and widths of plates

\begin{tabular}{ccc}
\hline $\mathbf{W}(\mathbf{m m})$ & $\mathbf{H}(\mathbf{m m})$ & $\begin{array}{c}\text { Difference between } \\
\text { heights }(\mathbf{m m})\end{array}$ \\
\hline 6000 & 1219.2 & 304 \\
6000 & 1524.0 & 304 \\
6000 & 1828.8 & 304 \\
6000 & 2133.6 & 304 \\
6000 & 2438.4 & --- \\
6000 & 3048.0 & --- \\
\hline
\end{tabular}

Table 4: Ranges for height modification

\begin{tabular}{cc}
\hline $\boldsymbol{H}_{\boldsymbol{M A X}}(\mathbf{m m})$ & $\boldsymbol{H}_{\boldsymbol{M A X}}(\mathbf{m m})$ \\
\hline $850 \sim 1500$ & 1219.2 \\
$1500 \sim 1755$ & 1524.0 \\
$1755 \sim 2049$ & 1828.8 \\
$2049 \sim 2650$ & 2134.0 \\
\hline
\end{tabular}




\subsection{Approach - 1 with Same Flange and Web Plate Thickness}

The methodology is to select the thickness of all webs and flanges to be almost equal to the average of $T_{T P}$ and $T_{S P}$ calculated in the previous methodologies. Hence, direct relationships are developed between the thicknesses of web or flange (as they are taken to be the same) with the capacity and span. These relations are different for different capacities and spans and are incorporated in the APDL code. As a case study, for 20 and $21 \mathrm{~m}$ span and $50 \sim 120$ ton capacity cranes, the plate thicknesses are calculated as mentioned in Table 5. The output stresses and deflections, thus produced, are within the allowable limits.

Table 5: Height Modification Thickness for $20 \mathrm{~m}$ and $21 \mathrm{~m}$ span girders

\begin{tabular}{ccc}
\hline Span (m) & Capacity (ton) & CPT (mm) \\
\hline 20 & $50 \sim 60$ & $((40+\mathrm{CC}) / 5)$ \\
& $60 \sim 95$ & $\left(\left(60+6^{*} \mathrm{CC}\right) / 30\right)$ \\
& $95 \sim 120$ & $\left(\left(5^{*} \mathrm{CC}-125\right) / 25\right)$ \\
21 & $50 \sim 55$ & 18 \\
& $55 \sim 85$ & $\left(\left(6^{*} \mathrm{CC}-5\right) / 25\right)$ \\
& $85 \sim 120$ & $\left(\left(6^{*} \mathrm{CC}-20\right) / 35\right)$ \\
\hline
\end{tabular}

\subsection{Width (WTP) Modification}

The width of the box girder was calculated to be $H_{M A X} / 2.71$ during previous optimizations. The ratio of $H_{M A X}$ to $W_{T P}$ (width of top plate) or $W_{B P}$ (width of bottom plate) was set as 3 i.e. cutting it into three pieces, hence saving the loss in height of the plate. This also follows the Bećirović et al. [37] recommendation that increasing the height to width ratio i.e. $\mathrm{H}_{\mathrm{MAX}} / \mathrm{W}_{\mathrm{TP}}$, increases the static as well as dynamic stability of the box girders.

\subsection{Approach-2: With Different Flange and Web Thickness (DFW)}

Using thicknesses initially calculated in the approach-1 and modifying the web and flange thicknesses so as to be ratios of approach-1 thicknesses. The study concluded that the web and flange plate thicknesses must be 0.9 times and 1.25 times of approach-1 thicknesses respectively. For example, if a thickness of $15 \mathrm{~mm}$ was concluded for a particular specification box girder, then the plate thicknesses used in approach-2 analysis will be 14 $\mathrm{mm}$ (i.e. $15 \times 0.9 \approx 14$ ) for the side plates and $19 \mathrm{~mm}$ (i.e. $15 \times 1.25 \approx 19$ ) will be used for the top and bottom flanges. As an example the mass calculated for 85 ton capacity and $26 \mathrm{~m}$ span crane box girder using approach-2 was $19742 \mathrm{~kg}$ i.e. $1047 \mathrm{~kg}(5.04 \%)$ less than the mass of the girder according to approach-1. Although the stresses and deflections are observed to be more than those observed for approach-1 but are still within the allowable limits.

\section{COMPARISON OF WOIC AND WIC OPTIMIZATION RESULTS}

This section compares the optimization results in a case when no standard size for height was used (old method), to the case when standard heights were used. Additionally, a comparison of cases where thicknesses of top/bottom and side plates were kept constant for approach-1 and not constant for approach-2 (diff-thick) were also used. Finally, the case with width modification is also compared with the prior. The aim of this comparison is to analyze the feasibility of the later optimizations. The case study presented shows results of carne capacity 120 ton box girders of various spans. Figure 10a-b show a comparison of 
mass, UZ, and $H_{M A X}$ results with and without considering industrial constraints. It is observed that as span increases, the difference between the old (WOIC) and new methodology (WIC-SFW) increases. The mass of a $32 \mathrm{~m}$ span WOIC and WIC optimized girder is $30060 \mathrm{~kg}$ and $36373 \mathrm{~kg}(\sim 21 \%$ increase), respectively (Fig. 10a). It concludes that the mass of the girders in WIC increases as compared to the WOIC during an increase in span length and/or capacity. A similar trend is observed with $\mathrm{W}_{\text {TP }}$ modification different thickness, but the difference is smaller in comparison to WIC-SFW. Abid et al. [30] have compared lateral buckling (UZ) for different designs of the box girders and have concluded that lateral buckling control is better for WIC compared to the WOIC. No notable difference in the bending deflections (UY) and shear buckling (UX). Figure 10b compares $H_{M A X}$ for the various case studies and shows that the height with WIC is smaller compared to WOIC and width of the girders is directly related to $\mathrm{H}_{\mathrm{MAX}}$, thus, the volume (space) occupied by the WIC is less than that of WOIC girders. The variety of plate sizes for manufacturing is greatly reduced as now the thickness of top and side plates is the same for the approach-1. Although the mass of the girders is increased with WIC methodology yet it is inconclusive to state that it is not cost effective, as cost effectiveness can only be known after knowing the cutting and welding as well as material costs for manufacturing and the already available inventory. Therefore, approach- 2 is proposed as the final design for the box girders. The cutting plan and welding methodologies are all based on this particular design. The features of the finalized design are summarized below;

- The height of the girder web plate is selected as per ranges defined in the Table 4.

- The width of the flange plates (both top and bottom) is one-third of the maximum height of the girder web plate.

- The ratio of thickness top/bottom flange to the web plates is 1.389 .

- All horizontal stiffeners and rail sections are selected according to the standard library.

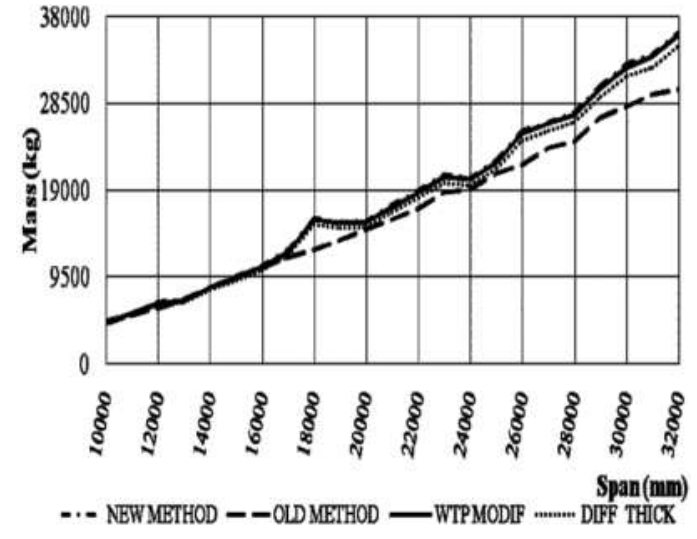

(a)

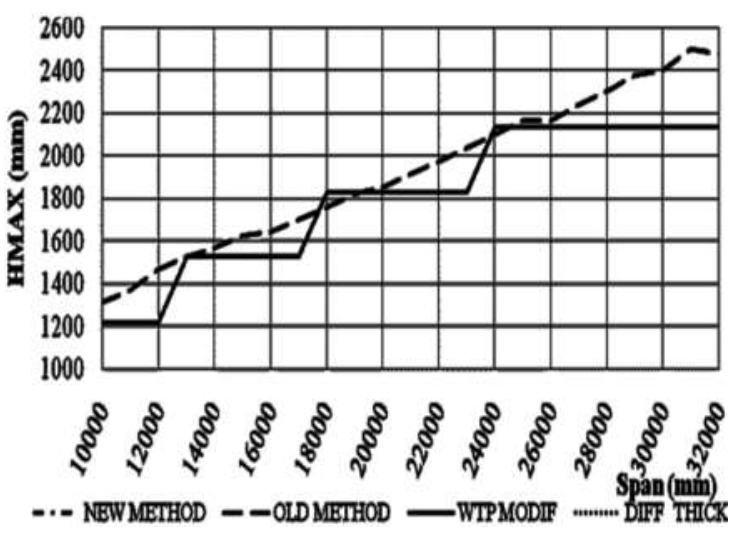

(b)

Fig. 9: Comparisons for 120 ton capacity with different spans; (a) mass, (b) $H_{M A X}$. 


\section{CONCLUSIONS}

After detailed FEA of box girders, the following conclusions are made;

- Optimization of an overhead crane box girder for capacity (50 120 ton) and span $(10 \sim 32 \mathrm{~m})$ is performed for safe bending stress and deflection with minimum mass and volume with and without consideration of industrial constraints using a customized developed optimization resulting in accuracy and automation.

- The cutting and welding plan is optimized to reduce wastage and control manufacturing overheads.

- The finite element model used solid186 elements because their use offers better control during parametric modeling. The shell elements on the other hand are not suitable for horizontal stiffener and rail sections as they cannot be treated as shells. Also, after the inclusion of height modification in the height reduction in specific cases is made possible at the cost of thickness addition, thus, the error in shell element calculation is avoided.

- The parametric optimization of the reference girder $(120$ ton $\times 32 \mathrm{~m})$ concluded a $14.63 \%$ (or $5449 \mathrm{~kg}$ ) mass reduction, $27.3 \%$ and $2.18 \%$ thickness reduction of web and flange plates respectively with respect to the existing box girder model. Similar savings are observed in all the range of capacity and spans.

- Linear interpolated capacity-wise and span-wise relations were developed for the calculation of the design parameters $\left(H_{M A X}, P T\right.$ and $\left.R D\right)$ for the required capacity (50 ton $\sim 120$ ton) and span $(10 \mathrm{~m} \sim 32 \mathrm{~m}$ ) of the box girder. Before performing spanwise optimization, with the only input as span and fixed capacity (100 ton), mesh sensitivity analysis was carried out and an element edge length of $170 \mathrm{~mm}$ was concluded (for a 100 ton girder).

- The combined optimization using combination/correction factors was performed in three steps (capacity, correction and span control block).

- The optimized parameters concluded were modified according to the industrial constraints i.e. standard section libraries of plates and rolled sections available in the market. The addition of standard libraries increased the mass of the girder as the code selected an upper bound thickness.

- The height of the girder $\left(H_{M A X}\right)$, as calculated during the earlier optimizations, was modified keeping in mind the losses during the crane construction. $H_{M A X}$ was concluded to be equal to the size of a given standard plate to avoid cutting along the height of the web. $\mathrm{W}_{\text {TP }}$ was concluded to be $1 / 3$ of the height of the girder $\left(H_{M A X}\right)$. Two optimization studies were performed to modify the height considering first web and flange thicknesses to be equal (approach-1), and secondly top/bottom plate thickness of 0.9 times and 1.25 times the thickness calculated in approach-1. All the optimization case studies performed were compared and it was concluded that the case studies with no height modifications had lower masses for greater spans $(15 \mathrm{~m}$ $\sim 32 \mathrm{~m}$ ). The addition of mass due to height modification increases with the increase in both span and capacity. Hence, the mass of the height modified cases for lower spans was observed to be less than the non-modified case studies. 


\section{REFERENCES}

[1] Zuberi RH, Kai L, Zhengxing Z. (2008) Design Optimization of EOT Crane Bridge. EngOpt 2008 - International Conference on Engineering Optimization. 01 - 05 June 2008; Rio de Janeiro, Brazil.

[2] Lerga JI. (2011) Modelling and Simulation Research on the Metal Structure of Bridge Cranes. M.Sc. Thesis, Technical University - Sofia English Language Faculty of Engineering, Sofia.

[3] Satyanarayana, V.V., Ghosh, D. P. and Rao, J.S. (1980) Dynamic Response of the Bridge Girders of E.O.T. Cranes due to Dissimilar Rail Joints. Mechanism and Machine Theory; 15, 385-395.

[4] Cranes [http://crawlercrane.net/solution/cranes/crane-introduction.html]

[5] Swuste, P. (2013) A normal accident with a tower crane? An accident analysis conducted by the Dutch Safety Board. Safety Science; 57, 276-28.

[6] Zhang, C. and Hammad, A. (2012) Improving lifting motion planning and re-planning of cranes with consideration for safety and efficiency. Advanced Engineering Informatics; 26, 396-410.

[7] Tam, V.W.Y., and Fung, I.W.H. (2011) Tower crane safety in the construction industry: A Hong Kong study. Safety Science; 49, 208-215.

[8] Marquez, A.A., Venturino, P. and Otegui, J.L. (2014) Common root causes in recent failures of cranes. Engineering Failure Analysis; 39, 55-64.

[9] Ruud, S. and Mikkelsen, Å. (2008) Risk-based rules for crane safety systems. Reliability Engineering and System Safety; 93, 1369-1376.

[10] Navestad, T.O.(2008) Safety understandings among crane operators and process operators on a Norwegian offshore platform, Safety Science; 46, 520-534.

[11] Lei, Z., Taghaddos, H., Hermann, U. and Al-Hussein, M. (2013) A methodology for mobile crane lift path checking in heavy industrial projects, Automation in Construction; 31, 41-53.

[12] Li, Y. and Liu, C. (2012) Integrating field data and 3D simulation for tower crane activity monitoring and alarming. Automation in Construction. 27, 111-119.

[13] Rusiński, E. Iluk, A., Malcher, K., Pietrusiak, D. (2013) Failure analysis of an overhead traveling crane lifting system operating in a turbo generator hall. Engineering Failure Analysis; 31, 90-100.

[14] Aneziris, O.N. (2008) Towards risk assessment for crane activities. Safety Science; 46, 872884.

[15] Shepherd, G.W., Kahler, R.J. and Cross, J. (2000) Crane fatalities - a taxonomic analysis. Safety Science; 36, 83-93.

[16] American Society of Mechanical Engineers, (2010) Overhead and Gantry Cranes - Top Running Bridge, Single or Multiple Girder, Top Running Trolley Hoist. ASME B30.2-2005. Three Park Avenue $\bullet$ New York, NY.

[17] International Organization for Standardization (2005). Cranes -Design principles for loads and load combinations, Part 4 Jib Cranes, ISO 8686-4:2005; 1, 1-9. ISO, Geneva, Switzerland.

[18] The Crane Manufacturers Association of America (2015). Specification \# 70, Specifications for Top Running Bridge \& Gantry Type Multiple Girder Electric Overhead Traveling Cranes; 1-8. CMAA, USA.

[19] Anon (1995b), DIN: Taschenbuch 185, Fördertechnik 2, Berlin: Beuth-Verlag.

[20] Fédération Européenne de la Manutention (1998) FEM 1.001 Rules for the design of hoisting appliances, 3rd Edition, 8 booklets, 1-305. Technos Publicações Ltda, Brazil.

[21] British Standard Institution (2012) Code of practice for the safe use of cranes. Inspection, maintenance and thorough examination. Mobile cranes. 1-32, BSI, London, UK. (ISBN: 978058078194 0)

[22] Polish Standard. (1990) Steel construction - Static calculations and design. Polish Standard PN-B-03200:1990, 1-48. Standardization Publishing House. Poland.

[23] Greiner, H.G. (1967) Crane Handbook: Design Data and Engineering Information used in the Manufacture and Application of Cranes. Whiting Corporation, Harvey III, USA, $3^{\text {rd }}$ Ed. 1206. 
[24] Otani, A. Nagashima, K. and Suzuki, J. (2002) Vertical seismic response of overhead crane. Nuclear Engineering and Design; 212, 211-220.

[25] Alkin, C., Imrak, C.E. and Kocabas, H. (2005) Solid Modeling and Finite Element Analysis of an Overhead Crane Bridge. Acta Polytechnica, Czech Technical University in Prague; 45, 61-67.

[26] Farkas, J. (1986) Economy of Higher-Strength Steels in Overhead Travelling Cranes with Double-Box Girders. Journal of Construction Steel Research; 6, 285-301.

[27] Niezgodzin, T. and Kubiak, T. (2005) The problem of stability of web sheets in box-girders of overhead cranes. Thin-Walled Structures; 43, 1913-1925.

[28] Imrak, C.E., Gerdemeli, I. and Erdik, A. (2006) Linear and Nonlinear Finite Element Modelling and Stress Analysis of Portal Cranes. Proc. of $10^{\text {th }}$ International Research/Expert Conference, Trends in the Development of Machinery and Associated Technology, Barcelona-Lloret de Mar, Spain, 793-796.

[29] Blum, A., and Chodorowska, D. (2007) Experimental analysis of prestressed thin-walled structures stability. Thin-Walled Structures; 45, 834-839.

[30] Abid, M., Akmal, M.H. and Parvez, S. (2008) Optimization of box girder of Overhead Crane," Global Design to Gain a Competitive Edge: An Holistic and Collaborative Design Approach Based on Computational Tools. 609-617.

[31] Pinca, C.B., Tirian, G.O. and Socalici, A.V. (2009) Application of finite element method to an overhead crane bridge. WSEAS Transactions on Applied and Theoretical Mechanics; 2/4, 64-73.

[32] Pinca, C.B., Tirian, G.O. Socalici, A.V. and Ardelean, E.D. (2009) Dimensional optimization for the strength structure of a traveling crane. WSEAS Transactions on Applied and Theoretical Mechanics; 4/4, 147-156.

[33] Gerdemeli, S. Kurt, H. and Alkan, O. (2010) Main Girder Beam Design and Finite Element Analysis of 2x160ton Gantry Crane. Proc. 14th International Research/Expert Conference. Trends in the Development of Machinery and Associated Technology. Mediterranean Cruise. $565-568$.

[34] Gerdemeli, S., Kurt, H. and Yildirim, M. (2010) Calculations, Modeling and Analysis with Finite Element Method of Rubber Tyred Container Stacking Crane. 14 ${ }^{\text {th }}$ International Research/Expert Conference. Trends in the Development of Machinery and Associated Technology. Mediterranean Cruise. 545-548.

[35] Gašić, V., Milovančević, M. and Petković, Z. (2010) FEA Implementation in Moving Load Problem at Bridge Cranes. University of Novi Sad, Faculty Of Technical Sciences, Adeko Association For Design, Elements And Constructions, Ceepus Cii-Rs-0304 / Ceepus Cii-Pl0033, Machine Design; 25-30.

[36] Zhang, H., Roches, R.D., Yang, Z. and Liu, S. (2010) Experimental and analytical studies on a streamlined steel box girder. Journal of Constructional Steel Research; 66, 906-914.

[37] Bećirović, D., Vukojević, F. and Hadžikadunić. (2011) Optimization of Double Box Girder Overhead Crane in Function of Cross Section Parameter of Main Girders. $15^{\text {th }}$ International Research/Expert Conference Trends in the Development of Machinery and Associated Technology. Prague, Czech Republic; 641-644.

[38] Gąska, D. and C. Pypno, C. (2011). Strength and elastic stability of cranes in aspect of new and old design standards. Mechanika; 17/3, 226-231.

[39] Djelosevic, M., Gajic, V., Petrovic, D. and Bizic, M. (2012). Identification of local stress parameters influencing the optimum design of box girders. Engineering Structures; 40, 299 316.

[40] Abid, M., Khan, S.M. and Shah, A.R. (2013) Optimization of Box Type Girder of Overhead Crane for Different Capacities with Fixed Span. $9^{\text {th }}$ International Conference on Fracture and Strength of Solids, Jeju, Korea. 1-9.

[41] Abid, M. and Khan, S.M. (2014) Optimization of Box Type Girder of Overhead Crane for Different Spans with Fixed Capacity. International Conference on Industrial Engineering and Operations Management, Bali, Indonesia; 404-412. 
[42] Chauhan, N. and Bhatt, P.M. (2012) Improving the Durability of the E.O.T. Crane Structure by Finite Element Analysis, and Optimize the Hook Material for Improving its Solidity. Procedia Engineering; 38, 837-842.

[43] Suratkar, V. S. (2013) 3D Modelling and Finite Element Analysis of EOT Crane. International Journal of Mechanical and Production Engineering; 1/2, 34-37.

[44] Rabey, V. The Study of a Stress-Strain State of Bridge Cranes, Metal Constructions in the Process of a Collision with the End Stops. Faculty of Mechanical Engineering, Astrakhan, FME Transactions; 41, 195-201.

[45] Haniszewski, T. (2014) Strength Analysis of Overhead Traveling Crane with Use of Finite Element Method. Transport Problems; 9/1, 19-26.

[46] American Society for Testing and Materials (1999) ASTM A36: Standard Specification for Carbon Structural Steel. 46 CFR 160.035-3(b)(2), USA.

[47] ANSYS. (2010) Element Reference Manual. ANSYS Inc. USA.

[48] State Steel Supply Company (2014) State Steel Product Catalogue. Rev. 7/03. USA.

[49] Ambrose, J. and Tripeny, P. (2011) Building Structures, 3rd Edition, ISBN: 978-0-470-542606. 